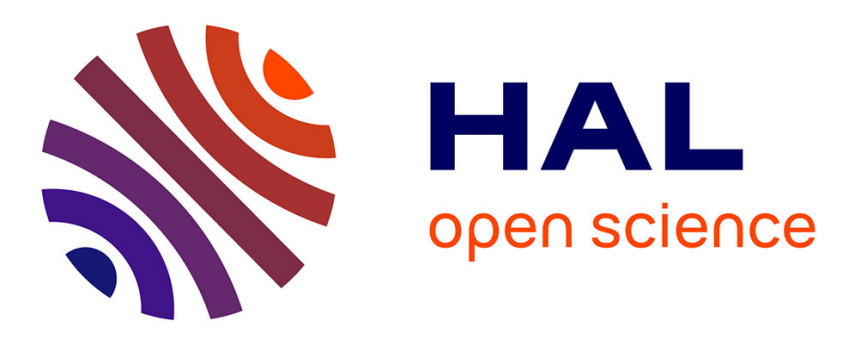

\title{
Design and Structure Determination of a Composite Zinc Finger Containing a Nonpeptide Foldamer Helical Domain
}

\author{
Caterina Maria Lombardo, Vasantha Kumar M. V., Céline Douat, Frederic \\ Rosu, Jean-Louis Mergny, Gilmar Salgado, Gilles Guichard
}

\section{To cite this version:}

Caterina Maria Lombardo, Vasantha Kumar M. V., Céline Douat, Frederic Rosu, Jean-Louis Mergny, et al.. Design and Structure Determination of a Composite Zinc Finger Containing a Nonpeptide Foldamer Helical Domain. Journal of the American Chemical Society, 2019, 141 (6), pp.2516-2525. 10.1021/jacs.8b12240 . hal-02161413

\section{HAL Id: hal-02161413 https://hal.science/hal-02161413}

Submitted on 4 Nov 2019

HAL is a multi-disciplinary open access archive for the deposit and dissemination of scientific research documents, whether they are published or not. The documents may come from teaching and research institutions in France or abroad, or from public or private research centers.
L'archive ouverte pluridisciplinaire HAL, est destinée au dépôt et à la diffusion de documents scientifiques de niveau recherche, publiés ou non, émanant des établissements d'enseignement et de recherche français ou étrangers, des laboratoires publics ou privés. 


\section{Design and Structure Determination of a Composite Zinc Finger Containing a Non-peptide Foldamer Helical Domain}

Caterina Maria Lombardo, ${ }^{1, \S}$ Vasantha Kumar M. V., ${ }^{2, \$, \uparrow}$ Céline Douat, ${ }^{1}$ Frédéric Rosu, ${ }^{3}$ Jean-Louis Mergny, ${ }^{2}$ Gilmar Salgado, ${ }^{2 *}$ Gilles Guichard ${ }^{1 *}$

${ }^{1}$ Univ. Bordeaux, CNRS, CBMN, UMR 5248, Institut Européen de Chimie et Biologie, 2 rue Robert Escarpit, 33607 Pessac, France.

${ }^{2}$ Univ. Bordeaux, Inserm, CNRS, ARNA Laboratory, U1212, UMR 5320, Institut Européen de Chimie et Biologie, 2 rue Robert Escarpit, 33076 Pessac, France.

${ }^{3}$ Institut Européen de Chimie et Biologie, UMS3033/US001, Université de Bordeaux, INSERM, CNRS, 2 rue Robert Escarpit, 33076 Pessac, France.

${ }^{s_{E}}$ qual contribution

${ }^{\dagger}$ Current address: University of South Florida 3720 Spectrum Blvd., Suite 105, Tampa, Florida 33612, USA

${ }^{*}$ Correspondence to: g.guichard@iecb.u-bordeaux.fr

*Correspondence to: gilmar.salgado@u-bordeaux.fr 


\section{ABSTRACT}

A number of foldamer backbones have been described as useful mimics of protein secondary structure elements, enabling for example the design of synthetic oligomers with the ability to engage specific protein surfaces. Synthetic folded backbones can also be used to create artificial proteins in which a folded peptide segment (e.g. an a-helix, a loop) is replaced by its unnatural counterpart, with the expectation that the resulting molecule would maintain its ability to fold while manifesting new exploitable features. The similarities in screw sense, pitch and polarity between peptide $\alpha$-helices and oligourea 2.5 -helices suggest that a tertiary structure could be retained when swapping the two backbones in a protein sequence. In the present work we move a step towards the creation of such composite proteins by replacing the 10-residue long original $\alpha$-helical segment in the Cys2His2 zinc finger 3 of transcription factor Egr1 (also known as Zif268) by an oligourea sequence bearing two appropriately spaced imidazole side chains for zinc coordination. We show by spectroscopic techniques and mass spectrometry analysis under native conditions that the ability of the peptide/oligourea hybrid to coordinate zinc ion is not affected by the foldamer replacement. Moreover, detailed NMR analysis provides evidence that the engineered zinc finger motif adopts a folded structure in which the native beta-sheet arrangement of the peptide region and global arrangement of DNA binding side chains are preserved. Titration in the presence of Egr1 target DNA sequence supports binding to GC bases as reported for the wild type zinc finger.

Keywords: Zinc finger, oligourea foldamer, NMR structure, protein prosthesis, helix mimicry 


\section{INTRODUCTION}

Recent progress in the creation of artificial proteins with accurate control over chemical composition, three-dimensional structure, and appending functionalities ${ }^{1-6}$ open avenues for a range of downstream applications from therapeutics and delivery systems to catalysts and bionanomaterials. In this context, protein backbone engineering (protein prosthesis ${ }^{7}$ ), ${ }^{3}$ which benefits from current advances in the total chemical synthesis and semi-synthesis of proteins, ${ }^{8-12}$ can be used to interrogate protein folding, address the role of individual folded segments, modulate protein function and fine tune a range of properties among which immunogenicity, solubility, resistance to proteolytic degradation and cell permeability. A number of reports have investigated the effect of substituting the amide bond by surrogates, or small subsets of $\alpha$-residues in loop and turn segments by either constrained or more flexible mimics. ${ }^{7,10,13-21}$ Fewer studies, however, have reported composite proteins in which a larger folded segment (e.g. an $\alpha$-helix) was replaced by an artificial one. The ability to create isolated and stable artificial secondary structure elements from a variety of non-biological synthetic oligomeric backbones (i.e. foldamers ${ }^{22-24}$ ) either close or remote from natural biopolymers provides new opportunities to design and investigate such composite proteins. ${ }^{25}$ A noteworthy example is a semisynthetic analogue of human interleukin 8 (IL-8) in which the C-terminal $\alpha$-helix was replaced by a 14-residue long $\beta^{3}$-peptide sequence. ${ }^{26}$ Although the artificial chemokine retained significant biological activity, it should be noted that the incorporated $3{ }_{14}$-helical $\beta$-peptide segment differs from the original $\alpha$-helix in both handedness and dipole orientation. ${ }^{26,27}$ In the absence of high-resolution structural information, it is not possible to draw firm conclusion about the level of mimicry that was actually achieved in this system in terms of tertiary structure. Concurrently, structural details about the effect of multiple $\beta$-residue substitutions evenly distributed in a-helical segments of discrete tertiary structures (e.g., B1 domain of protein $\mathrm{G}$ from Streptococcus bacteria (GB1), ${ }^{28}$ villin headpiece subdomain, ${ }^{29}$ ) and within coiled coils (e.g., yeast transcriptional activator GCN4-derived peptides) $)^{30-32}$ have been reported independently by Gellman and Horne. In particular, the Horne group has shown that the GB1 tertiary fold can accommodate up to $20 \%$ unnatural residues (i.e., a combination of D-amino acid, aminoisobutyric acid, N-Me-amino acid, and $\beta^{3}$-amino acid replacements) strategically placed in different secondary structure elements (helix, loop, sheet, and turn) ${ }^{28}$ highlighting the substantial 
plasticity of the protein backbone.

Swapping a whole secondary structure element such as an a-helix with its foldamer counterpart in a protein context without causing major unfolding remains a challenge and ideally requires the two folded backbones to exhibit a high degree of similarity and complementarity in terms of shape and side chain distribution. We have previously reported that aliphatic N,N'-linked oligoureas, a class of non-peptidic foldamers that can be decorated with proteinogenic side chains, adopt a helical conformation closely resembling the $\alpha$-helix in terms of diameter, pitch, handedness, and polarity. ${ }^{33}$ Their stability in water and their high tunability have already been exploited to program the formation of complex assembled architectures, such as discrete helical bundles and channels. ${ }^{34-36}$ Furthermore, it has been shown in model chimeric molecules consisting of fused oligourea and $\alpha$ helical peptides segments (so called block co-foldamers), that the two helical structures both coexist and communicate. ${ }^{37-39}$ Although the canonical oligourea and peptide helices differ by the number of residues per helix turn (2.5 for oligoureas ${ }^{33}$ versus 3.6 for $\alpha$-peptides), an overlay of the two helical backbone reveals a relatively close match between a three-residue-long oligourea and an $\alpha$-helical tetrapeptide (Root-mean square deviations (RMSDs) calculated for four carbonyl C atoms and four $\mathrm{NHs}=0.7867 \AA$, Fig. 1a). This observation suggested to us that a composite foldamer protein could be generated by substituting an a-helical segment for a designed oligourea sequence of appropriate length, although care must be taken to preserve the distribution and space orientation of key side chains.

To test our ability to design such a foldamer-based mimic of a folded protein, we selected the Cys2His2 zinc finger motif. Zinc fingers are recurrent protein motifs (found in $2 \%$ of human genes) involved in specific duplex DNA recognition, whose folding properties have been extensively studied using native and simplified synthetic systems. ${ }^{40-43}$ Cys2His2 zinc fingers are (relatively) small and modular units of about 30 residues, which consist of two antiparallel strands of $\beta$-sheet connected by a turn, packed against an $\alpha$-helix. This archetypal $\beta \beta \alpha$ fold is stabilized by a single zinc ion coordinated by a pair of cysteine residues located in the $\beta$-sheet and a pair of histidine residues located at the C-terminus of the $\alpha$-helix in a tetrahedral geometry (Fig. 1b) ${ }^{42}$ Zinc coordination is playing a key role at directing folding of the motif and at correctly orienting a-helix residues in direct contact with DNA, and thus it is crucial that the histidine and cysteine side chains 
are properly displayed. To the best of our knowledge, only few studies have investigated the effect of side chain metal coordination for the stabilization of foldamer secondary ${ }^{44-49}$ or tertiary structures. ${ }^{50}$ Here, we selected Egr1 (Zif268), a transcription factor involved in cell proliferation and in the regulation of apoptosis as a target zinc finger protein. We describe the design and synthesis of a chimeric oligourea-zinc finger mimic whereby the native a-helically folded segment containing the two key histidines and the DNA -binding side chains has been replaced by an oligourea sequence (Fig. 1b). ${ }^{51-52}$ We have studied in detail the metal binding properties of the resulting composite protein by UV-Vis spectroscopy, circular dichroism (CD), ESI-MS and NMR analyses and have determined its three-dimensional solution structure by NMR spectroscopy. Our results show that we successfully conceived a composite zinc finger that mimic the native protein in different aspects such as folding, metal and DNA binding.

\section{RESULTS AND DISCUSSION}

Design and synthesis. We focused our efforts on one of the three zinc finger motifs of the zinc finger region (hereafter numbered from residue 1 to 90) of Egr1, namely finger 3 (Fig. 1b) encompassing residues 62-90. Examination of the X-ray crystal structure of a complex between a protein fragment encompassing the three fingers of Egr1 and a duplex DNA with a consensus binding site ${ }^{53,54}$ revealed that the $\alpha$-helix domain of finger 3 spans 11 residues (three helical turns) from Ser75 to His85. An overlay of the zinc finger helix with the X-ray crystal structure of a canonical oligourea helix ${ }^{34}$ suggested to us that the distribution and spacing of the two key imidazole side chains (His81 and His85) could be preserved by substituting a short oligourea segment of 8 residues (whose sequence is shown in Fig. 1c) for the residues Asp76-His85 of the a-helix. His-type side chains which are in a $\mathrm{i} / \mathrm{i}+4$ relationship in the natural peptide sequence, are in a $\mathrm{i} / \mathrm{i}+3$ relationship in the chimeric molecule. It is noteworthy that the side chains at the $\mathrm{N}$-terminus of the a-helix known to contact nucleobases in the major groove of DNA, namely Asp76 at P2, Glu77 at P3 and Arg80 at P6 have been maintained in the sequence of the cognate oligourea

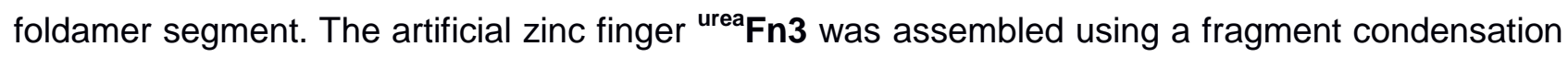
approach on solid support, taking advantage of the presence of a glycine residue in the sequence (Fig. 2a, supplementary methods). 
The hybrid C-terminus which contains the oligourea segment was synthesized on MBHA resin by microwave assisted solid-phase synthesis (SPS) using a set of N-Boc-protected-1,3-diamino monomers carrying the side chains of Ile, Lys, Asp, Glu and His (BB1-BB6) activated as succinimidyl carbamates for urea formation ${ }^{55,56}$ along with standard N-Boc $\alpha$-amino acids. The key monomer containing the $(1 \mathrm{H}$-imidazolyl-4yl)methyl side chain of histidine (BB6) was prepared from Trt-His(T-Trt)-OMe in seven steps with an overall yield of $35 \%$ as described previously. ${ }^{56}$ The fully protected $\mathrm{N}$-terminal fragment (residues 62-68) was synthesized on 2-chlorotrityl resin using $\mathrm{N}$ Fmoc a-amino acids (plus Boc-Pro-OH as last residue) and released by treatment with a 3:2 mixture of hexafluoroisopropanol (HFIP) and $\mathrm{CH}_{2} \mathrm{Cl}_{2}{ }^{57}$. It was then reacted directly with the $\alpha-$ amino function of the solid-supported C-terminal fragment in the presence of BOP and HOBt as

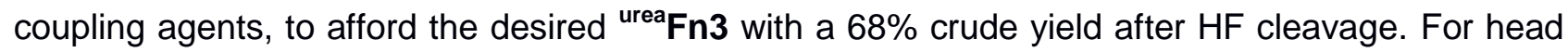
to head comparison, we also synthesized the native finger 3 peptide ( $\left({ }^{\text {native }}\right.$ Fn3) using standard SPS methodology and Fmoc strategy (see Supporting Information for details). Both ${ }^{\text {urea } F n 3 ~ a n d ~}{ }^{\text {native }}$ Fn3 were purified by preparative reversed-phase HPLC $\left(C_{18}\right)$ to a final purity of $>95 \%$, lyophilized and characterized by ESI-MS (Fig. 2b).

Metal binding properties of urea Fn3. The ability to coordinate $\mathrm{Zn}^{2+}$ cannot be directly assessed by UV-Vis spectroscopy, because $\mathrm{Zn}^{2+}$ has a full $\mathrm{d}^{10}$ shell, and is therefore UV silent. We thus performed a first titration experiment using $\mathrm{Co}^{2+}$, which is known to form complexes with the same geometry as $\mathrm{Zn}^{2+}$ and has a partially empty d-shell. A signal between 500 and $800 \mathrm{~nm}$, characteristic of the $\mathrm{d}-\mathrm{d}$ transition of a tetrahedral $\mathrm{Co}^{2+}$ complex was observed upon titrating both ${ }^{\text {urea }} \mathrm{Fn} 3$ and ${ }^{\text {native }} \mathrm{Fn} 3$ with $\mathrm{CoCl}_{2}$ (Fig. 3a and Supplementary Information).

A sharp end point was reached in both cases upon addition of 1 equivalent of metal, supporting a $1: 1$ stoichiometry for the complexes and strong binding. The zinc finger- $\mathrm{Co}^{2+}$ complexes were subsequently retro-titrated with $\mathrm{ZnCl}_{2}$, and for both compounds, a decrease of the signal in the visible region was observed, indicating a displacement of $\mathrm{Co}^{2+}$ by $\mathrm{Zn}^{2+}$ in the complex (Fig. $3 \mathrm{~b}$ and Supplementary Information). The stability of the two zinc finger- $\mathrm{Zn}^{2+}$ complexes was estimated by fitting the titration data to a 1:1 competitive binding model and very similar $K_{d}$ values were obtained $\left(K_{d}=2 \cdot 10^{-9} \mathrm{M}\right.$ for ${ }^{\text {urea }} \mathrm{Fn} 3-\mathrm{Zn}^{2+}$ and $6 \cdot 10^{-9} \mathrm{M}$ for $\left.{ }^{\text {native }} \mathrm{Fn3}-\mathrm{Zn}^{2+}\right)$. In contrast, the kinetics of $\mathrm{Co}^{2+}$ displacement varied between the two zinc fingers from 4 minutes for ${ }^{\text {urea }}$ Fn3, to 20 minutes for 
${ }^{\text {native }}$ Fn3 (see Supplementary Information). Since the end point of the direct titration with $\mathrm{Co}^{2+}$ was too sharp, the $K_{d}$ of the zinc finger- $\mathrm{Co}^{2+}$ complexes was determined in an independent UV titration experiment, by using $\mathrm{CoCl}_{2}$ in the presence of NTA as competitor $\left(K_{d} \mathrm{NTA}-\mathrm{Co}^{2+}=8.1 \cdot 10^{-8} \mathrm{M},{ }^{58}\right.$ see Supplementary Information). ${ }^{43}$

To gain additional insight into the effect of metal complexation on the overall tertiary structure, we also recorded $\mathrm{CD}$ spectra for the two $\mathrm{Zn}$ finger motifs at increasing concentrations of $\mathrm{Zn}^{2+}$. For ${ }^{\text {native }} \mathrm{Fn} 3$ a decrease in the negative molar ellipticity around $200 \mathrm{~nm}$ and an increase of the signal around $220 \mathrm{~nm}$ are observed upon $\mathrm{ZnCl}_{2}$ addition. A similar behavior was described in previous reports $^{59,60}$ and it is characteristic for the $\beta \beta \alpha$ arrangement of a zinc finger motif. The CD signature of ${ }^{\text {urea }}$ Fn3 differs substantially from the native domain: the molar ellipticity is positive around 200 $\mathrm{nm}$, which is attributable to oligourea 2.5-helical folding. Furthermore, a negative signal at $230 \mathrm{~nm}$, which decreases upon $\mathrm{ZnCl}_{2}$ addition, suggests a partial reorganization of the system upon metal binding (Fig. 3c and supplementary Fig S8). The titration end point was reached upon addition of 1 equivalent of the metal in agreement with UV-vis spectroscopy experiments and the formation of a 1:1 complex. The stoichiometry of the complex with $\mathrm{Zn}^{2+}$ was further supported by native mass spectrometry experiments (Fig.4). For both motifs, only the 1:1 complexes were observed in the presence $\mathrm{ZnAc}_{2}(3+$ and $4+$ charge states being the most populated regardless of the amount of metal added).

To further examine the metal binding profile of ${ }^{\text {urea }} \mathrm{Fn} 3$ in comparison with ${ }^{\text {native }} \mathrm{Fn3}$, we recorded ESI-MS spectra in the presence of equimolar amounts of $\mathrm{Zn}^{2+}, \mathrm{Co}^{2+}, \mathrm{Cd}^{2+}$ and $\mathrm{Hg}^{2+}$ and an excess of zinc finger in $100 \mathrm{mM} \mathrm{NH}_{4} \mathrm{OAc}, \mathrm{pH} \sim 6.8$ (Fig. 4b). By comparing the relative intensities of the species observed it was possible to estimate the relative stability of the complexes formed, and thus the metal binding preferences of each motif. However, since the affinity of $\mathrm{Hg}^{2+}$ for $\mathrm{NH}_{3}$ significantly differs from that of the other metal ions, $\mathrm{Hg}^{2+}$ being the most sequestered by $\mathrm{NH}_{3}$ (from $\mathrm{NH}_{4} \mathrm{Ac}$ ), care must be taken when interpreting intensity ratios with zinc finger- $\mathrm{Hg}^{2+}$ complexes. The 1:1 complex with $\mathrm{Zn}^{2+}$ and the 1:1 complex with $\mathrm{Co}^{2+}$ were the most abundant species detected with both native and urea-containing sequences. The two sequences were found to differ by their binding profile to heavy metals. Whereas only a weak signal corresponding to $1: 1$ complexes with $\mathrm{Cd}^{2+}$ and $\mathrm{Hg}^{2+}$ was observed for the native sequence, the chimeric motif was found to readily bind 
$\mathrm{Cd}^{2+}$ and $\mathrm{Hg}^{2+}$ as revealed by the intense peaks corresponding to the $1: 1$ complexes and also by the substantial amount of the $2: 1^{\text {urea }} \mathrm{Fn} 3-\mathrm{Cd}^{2+}$ complex in the ESI-MS spectrum.

${ }^{1} \mathrm{H}-\mathrm{NMR}$ analysis qualitatively supports folding of ${ }^{\text {urea }} \mathrm{Fn} 3$ upon Zinc coordination. Onedimensional ${ }^{1} \mathrm{H}$ NMR spectra of ${ }^{\text {urea }} \mathrm{Fn} 3$ were recorded in the absence and presence of one equivalent of $\mathrm{Zn}^{2+}$ metal ions in $10 \mathrm{mM}$ Sodium phosphate buffer (NaPi) buffer at $\mathrm{pH}$ 6.5. ${ }^{1} \mathrm{H}$ NMR spectral comparison, depicted in Fig. 5a show remarkable changes in the chemical shift dispersion upon zinc addition indicating structural fluctuation and conformational change. In the absence of zinc ${ }^{1} \mathrm{H}$ NMR spectra of ${ }^{\text {urea }}$ Fn3 show broader resonance lines and limited chemical shifts dispersion of $\mathrm{NH}$ (both amide and urea) signals, suggesting the absence of well-defined structure. Conversely, in the presence of zinc, the ${ }^{1} \mathrm{H}$ NMR spectra of urea ${ }^{2}$ 3 3 feature increased chemical shift dispersion of $\mathrm{NH}$ signals and sharp resonance peaks supporting the formation of a folded conformation as a result of metal coordination.

NOE analysis and structure calculation. Sequence-specific assignment of the $1: 1{ }^{\text {urea }} \mathrm{Fn} 3-\mathrm{Zn}$ complex was achieved using multiple multidimensional homonuclear and heteronuclear NMR experiments including 2D DQF-COSY, ${ }^{1} \mathrm{H}_{-}{ }^{15} \mathrm{~N} \mathrm{HSQC},{ }^{1} \mathrm{H}_{-}{ }^{13} \mathrm{C}$ edited HSQC,${ }^{1} \mathrm{H}-{ }^{1} \mathrm{H}$ TOCSY and ${ }^{1} \mathrm{H}-$ ${ }^{1} \mathrm{H}$ NOESY. High resolution 2D ${ }^{1} \mathrm{H}-{ }^{1} \mathrm{H}$ NOESY spectra obtained at high field $(950 \mathrm{MHz})$ were necessary to unambiguously assign and sequentially link each oligourea spin system. In the end, nearly $97 \%$ of the expected resonances for ${ }^{\text {urea }}$ Fn3-Zn were obtained (Fig. 5b, Supplementary Table S1).

Qualitative inspection of inter-residue NOEs extracted from NOESY experiments at $950 \mathrm{MHz}$ revealed several key features supporting folding of ${ }^{\text {urea } F n 3-Z n ~ i n t o ~ a ~ d e f i n e d ~ t e r t i a r y ~ s t r u c t u r e . ~}$ Firstly, the presence of repeated and typical medium range NOE cross peaks of the type $\mathrm{H} \alpha(I) / \mathrm{HN}(i+2)$ and $\mathrm{H} \alpha(I) / \mathrm{HN}^{2}(i+2)$ all along the oligourea segment is consistent with the formation of a canonical oligourea 2.5-helix as previously reported. ${ }^{61,62} \mathrm{~A}$ number of characteristic inter-residue NOEs are also observed in the peptide region encompassing residues 62-75. In addition to NOE

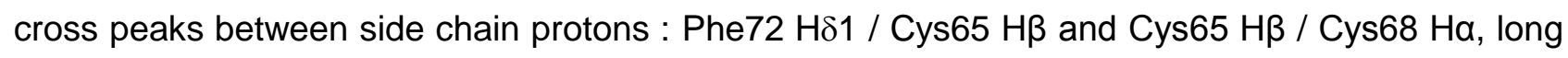
range NOEs between Phe72 HN and Ala64 Ha, Phe63 HN and Ala64 Ha, Asp66 Ha and Gly69 $\mathrm{HN}$, and Ile67 HN and Gly69 HN support the presence of a $\beta$-sheet structure. The long range NOEs observed between side chains of the $\beta$-sheet region and the oligourea helix/C-terminal 
tripeptide, such as those between $H \beta, H \gamma$ and $H \delta$ of lle67 and protons $H \delta 1$ and $H \varepsilon 1$ from His ${ }^{\cup} 83$, suggest that both parts are aligned side-by-side. Moreover, the following NOE cross peaks Cys65

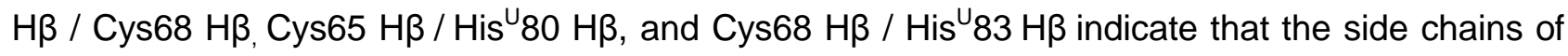
these ligand residues are in close spatial arrangement to satisfy zinc metal ion binding. The presence of NOE intra-residue crosspeaks between imidazole $\mathrm{H} \varepsilon 1$ with $\mathrm{H} \delta 1$ protons in $\mathrm{His} \mathrm{U}^{\mathrm{N}} 80$ and His ${ }^{\cup} 83$ residues confirmed protonation at the $N \delta$ position and that the $N \varepsilon$ position is free to coordinate zinc metal ion. The solution NMR structure of the $3.4 \mathrm{KDa}{ }^{\text {urea }}{ }^{2} \mathbf{3}-\mathrm{Zn}$ was calculated using 231 experimental NOE inter proton distances in combination with 22 torsional angles (for $\alpha-\mathrm{L}$ amino acids) and 32 weak hydrogen bond restraints for both natural and urea-type residues (Table S1) as described in the supplementary information. Briefly, NOE inter proton distance restraints were extracted from the in-depth analysis of 2D NOESY spectra acquired at different mixing time 120 and $250 \mathrm{~ms}$ and used for structure calculation in a simulated annealing protocol with AMBER 12 molecular dynamics package. ${ }^{63}$ The 200 best lower energy coordinates from vacuum simulation were selected for further minimization and 40 ps simulated annealing NMR refinement using generalized Bohr (GB) implicit solvent model. The 10 conformers with the lowest total energy were extracted from the MD trajectory and subjected to further refinement in an explicit water box with periodic boundary condition. The final structure ensemble is shown in Fig. 6a and structural statistics are given in Table S1.

Owing to the composite nature of ${ }^{\text {urea }}$ Fn3, the final NMR ensemble of conformers could not simply be checked with online structure validation tools. Structures of urea Fn3 were validated in two steps by first analyzing dihedral angles in the C-terminal oligourea segment over 40 ps of restrained molecular dynamics in comparison with values extracted from X-ray crystal structures of oligourea helices. $^{33,34}$ In a second step, the a-peptide segment in the structure (i.e. residues 62-75) was submitted to PROCHECK ${ }^{64}$ for validation.

Solution structure of ${ }^{\text {urea }} \mathrm{Fn} 3$ and comparison with the native fold. The solution structure of ${ }^{\text {urea }} \mathrm{Fn} 3-\mathrm{Zn}$ was obtained with a well-defined backbone core and a root-mean-square deviation (RMSD) of $0.35 \AA$. As shown in Fig. $6,{ }^{\text {urea }}$ Fn3 adopts a native-like tertiary structure consisting of a short antiparallel $\beta$ sheet connected to the helically folded oligourea segment. The structure is held 
together by tetrahedral zinc coordination of the two Cys residues in the peptide region and the imidazole side chains of the two $\mathrm{His}^{\cup}$ units in the 2.5-helix oligourea segment. A general feature of native $\beta \beta \alpha$ zinc fingers is the presence of a small hydrophobic core that brings additional stabilization to the structure and that generally involves a highly conserved aromatic residue (Phe72 in ${ }^{\text {native }}$ Fn3) packed edge to face against the proximal histidine (His81 in ${ }^{\text {native }}{ }^{\text {Fn3). }}$ Compared to the $\beta \beta a$ fold of ${ }^{\text {native }}$ Fn3 (PDB ID: 1 AAY),${ }^{54}$ the hydrophobic core in ${ }^{\text {urea }} \mathrm{Fn} 3$ is less compact because the loop connection between the $\beta$-strand and the helix region is more extended. This distortion of the loop segment may be due in part to the larger diameter of the oligourea helix compared to the $\alpha$-helix. However, the packing of the Phe72 over His $\cup 80$ is maintained. Conformational similarities and differences between ${ }^{\text {native }} \mathrm{Fn} 3$ and ${ }^{\text {urea }} \mathrm{Fn} \mathbf{3}$ are further highlighted by the structural alignment of the two $\mathrm{N}$-terminal peptide segments (13 to $13 \mathrm{Ca}$ atoms) which gives an average root-mean-square deviation of $1.166 \AA$ (calculated for the 10 lowest-energy structures (Fig. 6d).

\section{DNA binding properties of the chimeric ${ }^{\text {urea } F n 3 ~ z i n c ~ f i n g e r ~}$}

We next evaluated the ability of ${ }^{\text {urea }}$ Fn3 to interact with a short double-strand DNA sequence using chemical-shift mapping experiments and the Egr1 GC rich binding motif. First, the DNA imino region peak dispersion was monitored by $1 \mathrm{D}{ }^{1} \mathrm{H}$ NMR spectroscopy upon successive additions of

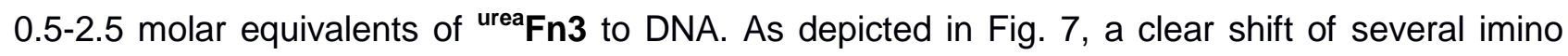
peaks was observed, notably $\mathrm{G} 2, \mathrm{G} 4$ and a third ambiguous $\mathrm{G}$ imino peak. ${ }^{1} \mathrm{H}-{ }^{1} \mathrm{H}$ NOESY experiments were used to tentatively assign imino peaks in the dense region between 12.7 and $12.9 \mathrm{ppm}$. The results seem to indicate that ${ }^{\text {urea }} \mathrm{Fn} 3$ binds to the 5' side of the leading strand DNA duplex d(5'- ${ }^{1}$ AGCGTGGGCG ${ }^{11}$ T-3') and d(3'- ${ }^{1}$ TCGCACCCGC ${ }^{11}$ A-5'). No important chemical shift variations were observed in the $3^{\prime}$ region of the leading strand $d\left(5^{\prime}-{ }^{1} A G C G T G G G C G{ }^{11} T-3^{\prime}\right)$. Apparent dissociation constants $\left(K_{\mathrm{d}}\right)$ were obtained by fitting the titration data to a single-site ligand-binding mode and were found to be in the range of $0.19-0.25 \mathrm{mM}$ (see the Supplementary Information and supplementary Fig. S9 for more details). These values are consistent with previous reports showing that a single Cys2His2 zinc finger domains bind with low affinity to DNA. ${ }^{65}$ High affinity recognition of DNA requires cooperativity and is achieved with protein domains 
containing three or more zinc fingers.

\section{CONCLUSIONS}

We have shown here that the structural resemblance between urea-based helical foldamers and $\alpha$ helical peptides can be exploited by combining the two backbones in a single chain to create protein mimics with defined tertiary structures. The design of the chimeric Cys2His2-type zinc finger reported in this work was guided by the knowledge of the structures of oligourea 2.5-helices at atomic resolution and was facilitated by their predictability, the helix folding propensity of urea oligomers being largely unaffected by the nature of the side-chains used. ${ }^{34}$ We observed that the metal binding ability of the composite zinc finger ( ${ }^{\text {urea }} \mathbf{F n} 3$ ) was fully retained upon substituting the $\alpha$-helix by the designed oligourea prosthesis, which indicates that the distribution of histidine-type side chains at the surface of the oligourea helix is fully compatible with the formation of a tetrahedral zinc complex. Furthermore, detailed NMR-derived 3D structure determination of the composite zinc finger in solution showed that the native beta-sheet arrangement of the peptide region was not compromised by helix swapping, and that a well-defined tertiary structure akin to the native fold was formed. Specific features of ureaFn3 such as an extended loop between the $\beta$ strand and the helix region and a less compact hydrophobic core compared to ${ }^{\text {native }} \mathbf{F n} 3$ may account for the differences in kinetics of metal exchange and binding selectivity observed between ${ }^{\text {urea }} \mathrm{Fn} 3$ and ${ }^{\text {native }}$ Fn3. Despite these differences, detailed inspection of the structure also revealed that overall the relative orientation of side chains involved in DNA binding by Cys2His2 Zinc fingers (namely Arg74, Asp ${ }^{\cup} 76$, Glu$^{\cup} 77$ and $\operatorname{Arg}^{\cup} 79$ corresponding to positions $-1,2,3$ and 6 of the $\alpha-$ helix) is relatively similar to that in the native zinc finger. The finding that ${ }^{\text {urea }}$ Fn3 binds DNA suggests that affinity could be increased significantly by incorporating it into a larger protein sequence containing multiple zinc finger motifs. It would then be tempting to evaluate how the foldamer replacement affects sequence specificity of DNA binding knowing that a given zinc finger motif is contacting three base pairs in a sequence dependent manner.

The approach reported in this work may prove to be more general and could be applied to other systems that fold without metals. The ability to combine synthetic oligourea foldamers and natural polypeptides to re-design proteins can be seen as a promising approach to create 
proteinomorphous objects with properties and possible applications beyond those known for natural proteins.

\section{EXPERIMENTAL SECTION}

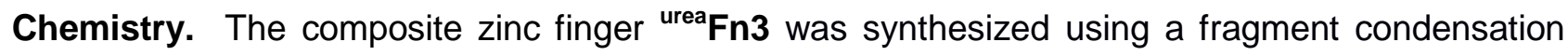
approach by coupling the fully protected peptide encompassing residues $62-69$ directly to the growing peptide/oligourea chain (residues 70-86) on the solid support. The 62-69 peptide segment was synthesized on a 2-chlorotrityl chloride resin using standard $\mathrm{N}$-Fmoc chemistry (at the exception of the final Pro residue incorporated as $\mathrm{N}$-Boc-Pro-OH), whereas the chimera was assembled by using $\mathrm{N}$-Boc protected amino acid residues and $\mathrm{N}$-Boc-protected succinimidyl carbamate building blocks for urea formation starting from a low-loading MBHA resin. The native zinc finger was synthesized on solid support by standard Solid-phase peptide synthesis using $N$ Fmoc-protected a-amino acid derivatives on low-loading Rink-amide MBHA resin. Additional details about chemical synthesis and purification and characterization of urea ${ }^{\mathrm{Fn} 3}$ and intermediates can be found in the Supplementary Information.

UV-vis and CD spectroscopy: All the samples were dissolved in phosphate buffer $20 \mathrm{mM} \mathrm{pH} 7.5$ and the measurements were performed under a positive atmosphere of Ar. The titrations were carried out in the presence of an excess of TCEP (about $0.5 \mathrm{mM}$ ), to ensure the complete reduction of the Cys residues. All the solutions used were previously purified through Chelex resin column (Bio-Rad), to eliminate any undesired metal contaminations, and degassed prior to use. For the elaboration of the data the dilution was taken into account and all the curves were corrected for the blank and the baseline adjusted to zero. The curves were fitted to the appropriate equilibrium using the software Origin 8.0. CD experiments were performed on a Jasco J-815 spectrometer. Data were recorded at $20^{\circ} \mathrm{C}$ with a speed of $50 \mathrm{~nm} / \mathrm{min}$ between wavelengths of 200 and $300 \mathrm{~nm}$, at $1 \mathrm{~nm}$ intervals and with an integration time of 2 seconds. Each measurement was repeated twice and averaged. For the elaboration of the data the dilution was taken into account and all the curves were corrected for the blank and the baseline adjusted to zero. Experimental details are provided in Supplementary Information. 
NMR spectroscopy, sequence specific assignment and restraints: Initial NMR experiments were performed at $298 \mathrm{~K}$, unless specified otherwise, using Bruker $700 \mathrm{MHz}, 800 \mathrm{MHz} \mathrm{NMR}$ spectrometers equipped with $5 \mathrm{~mm} \mathrm{TXI}$ and cryoprobe respectively, with the ability to apply pulse field gradient along z-axis. To obtain the sequence-specific-assignment of ${ }^{\text {urea }} \mathrm{Fn} 3$, a set of standard homonuclear NMR experiments including 2D ${ }^{1} \mathrm{H}-{ }^{1} \mathrm{H}$ DQF-COSY, 2D ${ }^{1} \mathrm{H}-{ }^{1} \mathrm{H}$ TOCSY (80 and 120 ms mixing time) and 2D ${ }^{1} \mathrm{H}-{ }^{1} \mathrm{H}$ NOESY (100, 150 and 300 ms mixing time) were recorded in solution contain $90 \% \mathrm{H}_{2} \mathrm{O}, 10 \% \mathrm{D}_{2} \mathrm{O}, \mathrm{NaOH}+\mathrm{HCl}$ buffer $(\mathrm{pH} 6.5,220 \mu \mathrm{L})$ under physiological condition. TOCSY spin systems were sequentially interlinked using sequential NOESY cross peak. With the help of sequence specific assignment, all inter-residue NOE distance restraints for exchangeable protons were obtained from 2D homonuclear ${ }^{1} \mathrm{H}-{ }^{1} \mathrm{H}$ NOESY spectra acquired with mixing times of 120 and 250 ms. To unambiguously assign non exchangeable protons, $2 \mathrm{D}{ }^{1} \mathrm{H}-{ }^{1} \mathrm{H}$ NOESY experiments (mixing time of $250 \mathrm{~ms}$ ) were performed on $800 \mathrm{MHz}$ using the same sample after lyophilization and re-hydration in $100 \% \mathrm{D}_{2} \mathrm{O}$ with the same final volume of $220 \mu \mathrm{L}$. To complement the homonuclear sequence-specific-assignment, a set of heteronuclear NMR experiments including $2 \mathrm{D}{ }^{1} \mathrm{H}-{ }^{15} \mathrm{~N},{ }^{1} \mathrm{H}-{ }^{13} \mathrm{C} \mathrm{HSQC}$ and ${ }^{1} \mathrm{H}-{ }^{13} \mathrm{C}$ NOESY experiments were performed on the same sample. Because of the presence of two amide protons $\left({ }^{1} \mathrm{H}^{N 1}{ }_{-}^{15} N_{1} \&{ }^{1} \mathrm{H}^{N 2}{ }^{15} N_{2}\right)$ in each urea units, both TOCSY and NOESY spectra contain the signals of two degenerated side chain (-R, Fig. 1a) frequencies that resonate over 1.3 ppm (between 5.6 ppm to 6.9 ppm) on F2 dimension. The number of oligourea amide protons together with side chain chemical shifts degeneracy (on F1 \& F2 dimensions) significantly contributed to poor spectral resolution and hampered the quality of NOESY spectra acquired on $800 \mathrm{MHz}$ spectrometer. To alleviate resonance crowding and to improve both resolution and quality of NMR spectra all the above listed experiments were repeated on the same sample $\left(90 \% \mathrm{H}_{2} \mathrm{O}, 10 \% \mathrm{D}_{2} \mathrm{O}, \mathrm{NaOH}+\mathrm{HCl}\right.$ buffer, pH 6.5, total $220 \mu \mathrm{L}$ ) on a $950 \mathrm{MHz}$ spectrometer equipped with a $5 \mathrm{~mm}$ cryogenically cooled probe-head with the z-axis pulse filed gradient (CERM, Florence). In all the experiments recycle delay was set to $1.5 \mathrm{~s}$ and water suppression was achieved by excitation sculpting method. Initial acquisition of ${ }^{1} \mathrm{H}-{ }^{15} \mathrm{~N}$ spectra with standard acquisition parameters (spectral width and offset) did not show all the expected peaks. Preliminary observation confirmed that oligourea amide proton ${ }^{1} \mathrm{H}^{N 2}$ and its directly bonded nitrogen ${ }^{15} \mathrm{~N}_{2}$ resonate far from the regular ${ }^{15} \mathrm{~N} /{ }^{1} \mathrm{H}^{N}$ chemical shift range, hence in 
$2 \mathrm{D}{ }^{1} \mathrm{H}-{ }^{15} \mathrm{~N}$ NMR experiment $\mathrm{F} 1$ dimension $\left({ }^{15} \mathrm{~N}\right)$ spectral offset was set to $100 \mathrm{ppm}$ with the total spectra width of 60ppm. For the rest of the listed NMR experiments, standard offset and spectral width were used. All NMR spectra were processed using topspin 3.2 (Bruker BioSpin) and SPARKY ${ }^{66}$ for spectra analysis and data interpretation.

Structure calculation and refinement in explicit solvent. NMR restrained based structure calculation of ${ }^{\text {urea }}$ Fn3 was performed using sander module of AMBER 12 (AMBER tool 14) and ff99SB force field ${ }^{67}$ by distance geometry simulated annealing in GB model and restrained molecular dynamics refinement in explicit solvent as described in Supplementary Methods.

\section{ACKNOWLEDGMENTS}

This work was funded in part by the CNRS and ANR (Project ANR-12-BS07-0019). A Marie Skłodowska-Curie postdoctoral fellowship (FP7-PEOPLE-2012-IEF-330825) to C.M.L. is gratefully acknowledged. The work on the $800 \mathrm{MHz}$ NMR spectrometer (IECB) was possible thanks to support from TGIR-RMN-THC Fr3050 CNRS, CNRS UMS3033, Inserm US001, Univ. Bordeaux. The project also received support from the Integrated structural biology (Instruct) program which is part of the European Strategy Forum on Research Infrastructures (ESFRI). We thank the personnel from the Center for Magnetic Resonance (CERM) Florence, Italy for the support during stay in Florence. G.G. also thank Olivier Sénèque and Valérie Gabélica for helpful discussions.

\section{ASSOCIATED CONTENT}

The Supporting Information is available free of charge on the ACS Publications website at DOI:

Characterization data of all compounds, spectroscopy experiments and supplementary methods, Figures S1-S9 and Table S1 (PDF).

\section{AUTHOR INFORMATION}

Corresponding Authors 
*gilmar.salgado@u-bordeaux.fr

*g.guichard@iecb.u-bordeaux.fr

\section{ORCID}

Frédéric Rosu : 0000-0003-3674-7539

Jean-Louis Mergny: 0000-0003-3043-8401

Gilmar Salgado: 0000-0002-0296-5979

Gilles Guichard: 0000-0002-2584-7502

\section{Notes}

${ }^{\S_{\text {Both }}}$ authors contributed equally to the work.

The authors declare no competing financial interest.

\section{REFERENCES:}

(1) Huang, P.-S.; Boyken, S. E.; Baker, D. The coming of age of de novo protein design. Nature 2016, 537, 320-327.

(2) Davis, L.; Chin, J. W. Designer proteins: applications of genetic code expansion in cell biology. Nat. Rev. Mol. Cell. Biol. 2012, 13, 168-182.

(3) Reinert, Z. E.; Horne, W. S. Protein backbone engineering as a strategy to advance foldamers toward the frontier of protein-like tertiary structure. Org. Biomol. Chem. 2014, 12, 87968802.

(4) Zhao, L.; Lu, W. Mirror image proteins. Curr. Opin. Chem. Biol. 2014, 22, 56-61.

(5) Bondalapati, S.; Jbara, M.; Brik, A. Expanding the chemical toolbox for the synthesis of large and uniquely modified proteins. Nat. Chem. 2016, 8, 407-418.

(6) Dang, B.; Wu, H.; Mulligan, V. K.; Mravic, M.; Wu, Y.; Lemmin, T.; Ford, A.; Silva, D.-A.; Baker, D.; DeGrado, W. F. De novo design of covalently constrained mesosize protein scaffolds with unique tertiary structures. Proc. Nat. Acad. Sci. U.S.A. 2017, 114, 10852-10857.

(7) Arnold, U.; Hinderaker, M. P.; Nilsson, B. L.; Huck, B. R.; Gellman, S. H.; Raines, R. T. Protein Prosthesis: A Semisynthetic Enzyme with a $\beta$-Peptide Reverse Turn. J. Am. Chem. Soc. 
2002, 124, 8522-8523.

(8) Agouridas, V.; El Mahdi, O.; Cargoet, M.; Melnyk, O. A statistical view of protein chemical synthesis using NCL and extended methodologies. Bioorg. Med. Chem. 2017, 25, 49384945.

(9) Kent, S. B. H. Total chemical synthesis of proteins. Chem. Soc. Rev. 2009, 38, 338351.

(10) Valverde, I. E.; Lecaille, F.; Lalmanach, G.; Aucagne, V.; Delmas, A. F. Synthesis of a Biologically Active Triazole-Containing Analogue of Cystatin A Through Successive Peptidomimetic Alkyne-Azide Ligations. Angew. Chem. Int. Ed. 2012, 51, 718-722.

(11) Harmand, T. J. R.; Murar, C. E.; Bode, J. W. New chemistries for chemoselective peptide ligations and the total synthesis of proteins. Curr. Opin. Chem. Biol. 2014, 22, 115-121.

(12) Levine, P. M.; Craven, T. W.; Bonneau, R.; Kirshenbaum, K. Semisynthesis of Peptoid-Protein Hybrids by Chemical Ligation at Serine. Org. Lett. 2014, 16, 512-515.

(13) Baca, M.; Kent, S. B. H.; Alewood, P. F. Structural engineering of the HIV-1 protease molecule with a $\beta$-turn mimic of fixed geometry. Protein Sci. 1993, 2, 1085-1091.

(14) Chapman, E.; Thorson, J. S.; Schultz, P. G. Mutational Analysis of Backbone Hydrogen Bonds in Staphylococcal Nuclease. J. Am. Chem. Soc. 1997, 119, 7151-7152.

(15) Viles, J. H.; Patel, S. U.; Mitchell, J. B. O.; Moody, C. M.; Justice, D. E.; Uppenbrink, J.; Doyle, P. M.; Harris, C. J.; Sadler, P. J.; Thornton, J. M. Design, synthesis and structure of a zinc finger with an artificial $\beta$-turn11Edited by M. F. Moody. J. Mol. Biol. 1998, 279, 973-986.

(16) Odaert, B.; Jean, F.; Melnyk, O.; Tartar, A.; Lippens, G.; Boutillon, C.; Buisine, E. Synthesis, folding, and structure of the $\beta$-turn mimic modified B1 domain of streptococcal protein G. Protein Sci. 1999, 8, 2773-2783.

(17) Kaul, R.; Angeles, A. R.; Jäger, M.; Powers, E. T.; Kelly, J. W. Incorporating $\beta$-Turns and a Turn Mimetic out of Context in Loop 1 of the WW Domain Affords Cooperatively Folded $\beta$ Sheets. J. Am. Chem. Soc. 2001, 123, 5206-5212.

(18) Horne, W. S.; Yadav, M. K.; Stout, C. D.; Ghadiri, M. R. Heterocyclic Peptide Backbone Modifications in an a-Helical Coiled Coil. J. Am. Chem. Soc. 2004, 126, 15366-15367.

(19) Tam, A.; Arnold, U.; Soellner, M. B.; Raines, R. T. Protein Prosthesis: 1,5- 
Disubstituted[1,2,3]triazoles as cis-Peptide Bond Surrogates. J. Am. Chem. Soc. 2007, 129, 12670-12671.

(20) Fuller, A. A.; Du, D.; Liu, F.; Davoren, J. E.; Bhabha, G.; Kroon, G.; Case, D. A.; Dyson, H. J.; Powers, E. T.; Wipf, P.; Gruebele, M.; Kelly, J. W. Evaluating $\beta$-turn mimics as $\beta$ sheet folding nucleators. Proc. Nat. Acad. Sci. U.S.A. 2009, 106, 11067-11072.

(21) Reinert, Z. E.; Musselman, E. D.; Elcock, A. H.; Horne, W. S. A PEG-Based Oligomer as a Backbone Replacement for Surface-Exposed Loops in a Protein Tertiary Structure. ChemBioChem 2012, 13, 1107-1111.

(22) Gellman, S. H. Foldamers: A Manifesto. Acc. Chem. Res. 1998, 31, 173-180.

(23) Goodman, C. M.; Choi, S.; Shandler, S.; DeGrado, W. F. Foldamers as versatile frameworks for the design and evolution of function. Nat. Chem. Biol. 2007, 3, 252-262.

(24) Guichard, G.; Huc, I. Synthetic foldamers. Chem. Commun. 2011, 47, 5933-5941.

(25) George, K. L.; Horne, W. S. Foldamer Tertiary Structure through Sequence-Guided Protein Backbone Alteration. Acc. Chem. Res. 2018, 51, 1220-1228.

(26) David, R.; Günther, R.; Baumann, L.; Lühmann, T.; Seebach, D.; Hofmann, H.-J.; Beck-Sickinger, A. G. Artificial Chemokines: Combining Chemistry and Molecular Biology for the Elucidation of Interleukin-8 Functionality. J. Am. Chem. Soc. 2008, 130, 15311-15317.

(27) Seebach, D.; Beck, A. K.; Bierbaum, D. J. The world of [beta]- and [gamma]peptides comprised of homologated proteinogenic amino acids and other components. Chem. Biodivers. 2004, 1, 1111-1239.

(28) Reinert, Z. E.; Lengyel, G. A.; Horne, W. S. Protein-like Tertiary Folding Behavior from Heterogeneous Backbones. J. Am. Chem. Soc. 2013, 135, 12528-12531.

(29) Kreitler, D. F.; Mortenson, D. E.; Forest, K. T.; Gellman, S. H. Effects of Single a-to$\beta$ Residue Replacements on Structure and Stability in a Small Protein: Insights from Quasiracemic Crystallization. J. Am. Chem. Soc. 2016, 138, 6498-6505.

(30) Horne, W. S.; Price, J. L.; Keck, J. L.; Gellman, S. H. Helix bundle quaternary structure from [alpha]/[beta]-peptide foldamers. J. Am. Chem. Soc. 2007, 129, 4178-4180.

(31) Horne, W. S.; Price, J. L.; Gellman, S. H. Interplay among side chain sequence, backbone composition, and residue rigidification in polypeptide folding and assembly. Proc. Nat. 
Acad. Sci. U.S.A. 2008, 105, 9151-9156.

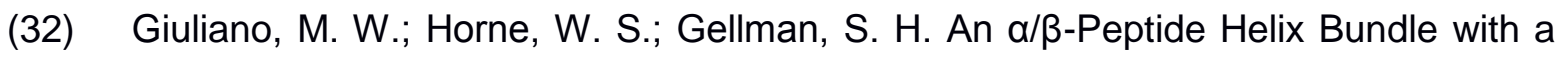
Pure ß3-Amino Acid Core and a Distinctive Quaternary Structure. J. Am. Chem. Soc. 2009, 131, 9860-9861.

(33) Fischer, L.; Claudon, P.; Pendem, N.; Miclet, E.; Didierjean, C.; Ennifar, E.; Guichard, G. The Canonical Helix of Urea Oligomers at Atomic Resolution. Insight Into Foldinginduced Axial Organization. Angew. Chem. Int. Ed. Engl. 2010, 49, 1067-1070.

(34) Collie, G. W.; Pulka-Ziach, K.; Lombardo, C. M.; Fremaux, J.; Rosu, F.; Decossas, M.; Mauran, L.; Lambert, O.; Gabelica, V.; Mackereth, C. D.; Guichard, G. Shaping quaternary assemblies of water-soluble non-peptide helical foldamers by sequence manipulation. Nat. Chem. 2015, 7, 871-878.

(35) Lombardo, C. M.; Collie, G. W.; Pulka-Ziach, K.; Rosu, F.; Gabelica, V.; Mackereth, C. D.; Guichard, G. Anatomy of an Oligourea Six-Helix Bundle. J. Am. Chem. Soc. 2016, 138, 10522-10530.

(36) Collie, G. W.; Bailly, R.; Pulka-Ziach, K.; Lombardo, C. M.; Mauran, L.; TaibMaamar, N.; Dessolin, J.; Mackereth, C. D.; Guichard, G. Molecular Recognition within the Cavity of a Foldamer Helix Bundle: Encapsulation of Primary Alcohols in Aqueous Conditions. J. Am. Chem. Soc. 2017, 139, 6128-6137.

(37) Maury, J.; Le Bailly, B.; Raftery, J.; Clayden, J. Conformational cooperativity between helical domains of differing geometry in oligoamide-oligourea foldamer chimeras. Chem. Commun. 2015, 51, 11802-11805

(38) Fremaux, J.; Mauran, L.; Pulka-Ziach, K.; Kauffmann, B.; Odaert, B.; Guichard, G. a-Peptide-Oligourea Chimeras: Stabilization of Short a-Helices by Non-Peptide Helical Foldamers. Angew. Chem. Int. Ed. 2015, 54, 9816-9820.

(39) Mauran, L.; Kauffmann, B.; Odaert, B.; Guichard, G. Stabilization of an a-helix by short adjacent accessory foldamers. C. R. Chimie 2016, 19, 123-131.

(40) Pabo, C. O.; Peisach, E.; Grant, R. A. Design and selection of novel cys2his2 zinc finger proteins. Annu. Rev. Biochem. 2001, 70, 313-340.

(41) Wolfe, S. A.; Nekludova, L.; Pabo, C. O. DNA recognition by Cys2His2 zinc finger 
proteins. Annu. Rev. Biophys. Biomol. Struct. 2000, 29, 183-212.

(42) Berg, J. M.; Godwin, H. A. Lessons from zinc-binding peptides. Annu. Rev. Biophys. and Biomol. Struct. 1997, 26, 357-371.

(43) Sénèque, O.; Latour, J.-M. Coordination Properties of Zinc Finger Peptides Revisited: Ligand Competition Studies Reveal Higher Affinities for Zinc and Cobalt. J. Am. Chem. Soc. 2010, 132, 17760-17774.

(44) Rossi, F.; Lelais, G.; Seebach, D. Zn2+-Complexation by a $\beta$-Peptidic Helix and Hairpin Containing $\beta 3$ hCys and $\beta 3 \mathrm{hHis}$ Building Blocks: Evidence from CD Measurements. Preliminary Communication. Helv. Chim. Acta 2003, 86, 2653-2661.

(45) Wortmann, A.; Rossi, F.; Lelais, G.; Zenobi, R. Determination of zinc to beta-peptide binding constants with electrospray ionization mass spectrometry. J. Mass Spectrom. 2005, 40, 777-784.

(46) Lelais, G.; Seebach, D.; Jaun, B.; Mathad, R. I.; Flögel, O.; Rossi, F.; Campo, M.; Wortmann, A. $\beta$-Peptidic Secondary Structures Fortified and Enforced by Zn2+ Complexation - On the Way to $\beta$-Peptidic Zinc Fingers? Helv. Chim. Acta 2006, 89, 361-403.

(47) Maayan, G.; Ward, M. D.; Kirshenbaum, K. Metallopeptoids. Chem. Commun. 2009, 56-58.

(48) Baskin, M.; Maayan, G. Water-soluble chiral metallopeptoids. Biopolymers 2015, 104, 577-584.

(49) Baskin, M.; Maayan, G. A rationally designed metal-binding helical peptoid for selective recognition processes. Chem. Sci. 2016, 7, 2809-2820.

(50) Lee, B.-C.; Chu, T. K.; Dill, K. A.; Zuckermann, R. N. Biomimetic Nanostructures: Creating a High-Affinity Zinc-Binding Site in a Folded Nonbiological Polymer. J. Am. Chem. Soc. 2008, 130, 8847-8855

(51) A preliminary version of his work was presented as a poster at the 24th American Peptide Symposium, June 20-25 2015, orlando, USA.

(52) After the present work was completed, a report appeared from the Horne group describing an artificial zinc finger containing several b-amino acids with the ability to adopt a native tertiary structure: George, K. L.; Horne, W. S. Heterogeneous-Backbone Foldamer Mimics of Zinc 
Finger Tertiary Structure. J. Am. Chem. Soc. 2017, 139, 7931.

(53) Pavletich, N.; Pabo, C. Zinc finger-DNA recognition: crystal structure of a Zif268DNA complex at 2.1 A. Science 1991, 252, 809-817.

(54) Elrod-Erickson, M.; Rould, M. A.; Nekludova, L.; Pabo, C. O. Zif268 protein-DNA complex refined at 1.6 A: a model system for understanding zinc finger-DNA interactions. Structure 1996, 4, 1171-1180.

(55) Douat-Casassus, C.; Pulka, K.; Claudon, P.; Guichard, G. Microwave-Enhanced Solid-Phase Synthesis of N,N '-Linked Aliphatic Oligoureas and Related Hybrids. Org. Lett. 2012, 14, 3130-3133.

(56) Nelli, Y.-R.; Douat-Casassus, C.; Claudon, P.; Kauffmann, B.; Didierjean, C.; Guichard, G. An activated building block for the introduction of the histidine side chain in aliphatic oligourea foldamers. Tetrahedron 2012, 68, 4492-4500.

(57) Bollhagen, R.; Schmiedberger, M.; Barlos, K.; Grell, E. A new reagent for the cleavage of fully protected peptides synthesised on 2-chlorotrityl chloride resin. Chem. Commun. 1994, 2559-2560.

(58) Martell, A. E.; Smith, R. M.: Critical stability constants; Plenum Press, 1975.

(59) Frankel, A. D.; Berg, J. M.; Pabo, C. O. Metal-dependent folding of a single zinc finger from transcription factor IIIA. Proc. Nat. Acad. Sci. U.S.A. 1987, 84, 4841-4845.

(60) Fehr, F.; Nadler, A.; Brodhun, F.; Feussner, I.; Diederichsen, U. Semi-Synthesis and Analysis of Chemically Modified Zif268 Zinc-Finger Domains. ChemistryOpen 2012, 1, 26-32.

(61) Violette, A.; Averlant-Petit, M. C.; Semetey, V.; Hemmerlin, C.; Casimir, R.; Graff, R.; Marraud, M.; Briand, J.-P.; Rognan, D.; Guichard, G. N,N'-Linked Oligoureas as Foldamers: Chain Length Requirements for Helix Formation in Protic Solvent Investigated by Circular Dichroism, NMR Spectroscopy, and Molecular Dynamics. J. Am. Chem. Soc. 2005, 127, 21562164.

(62) Guichard, G.; Violette, A.; Chassaing, G.; Miclet, E. Solution structure determination of oligoureas using methylene spin state selective NMR at ${ }^{13} \mathrm{C}$ natural abundance. Magn. Reson. Chem. 2008, 46, 918-924.

(63) Case, D. A.; Darden, T. A.; Cheatham, T. E.; Simmerling, C. L.; Wang, J.; Duke, R. 
E.; Luo, R.; Walker, R. C.; Zhang, W.; Merz, K. M.; Roberts, B.; Hayik, S.; Roitberg, A.; Seabra, G.; Swails, J.; Goetz, A. W.; Kolossváry, I.; Wong, K. F.; Paesani, F.; Vanicek, J.; Wolf, R. M.; Liu, J.; Wu, X.; Brozell, S. R.; Steinbrecher, T.; Gohlke, H.; Cai, Q.; Ye, X.; Wang, J.; Hsieh, M. J.; Cui, G.; Roe, D. R.; Mathews, D. H.; Seetin, M. G.; Salomon-Ferrer, R.; Sagui, C.; Babin, V.; Luchko, T.; Gusarov, S.; Kovalenko, A.; Kollman, P. A.: AMBER 12. University of California, San Francisco, 2012.

(64) Laskowski, R. A.; MacArthur, M. W.; Moss, D. S.; Thornton, J. M. PROCHECK: a program to check the stereochemical quality of protein structures. J. App. Cryst. 1993, 26, 283291.

(65) Nedved, M. L.; Moe, G. R. Cooperative, non-specific binding of a Zinc finger peptide to DNA. Nucleic Acids Res. 1994, 22, 4705-4711.

(66) Goddard, T. D.; Kneller, D. G.: SPARKY 3. University of California, San Francisco., 2008.

(67) Hornak, V.; Abel, R.; Okur, A.; Strockbine, B.; Roitberg, A.; Simmerling, C. Comparison of multiple Amber force fields and development of improved protein backbone parameters. Proteins 2006, 65, 712-725. 


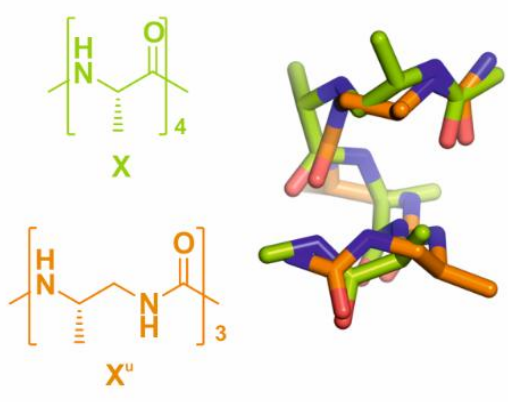

b

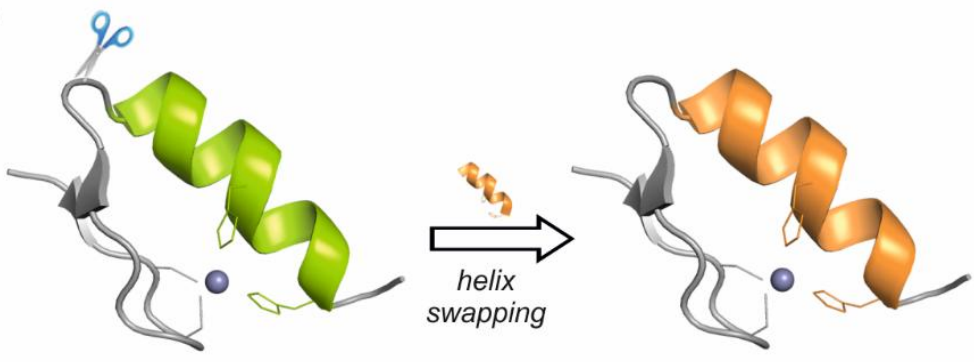

C

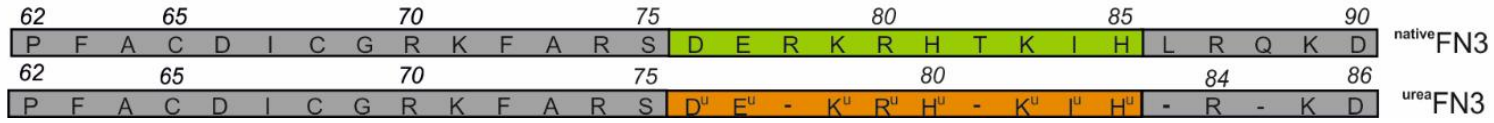

Figure 1. Design guided by the structure of composite proteins containing artificial helical foldamer region. a, Comparison of $\alpha$-peptide (green) and oligourea (orange) backbones and overlay of their helical structures ( $\alpha$-helical tetrapeptide vs 2.5-helical triurea) illustrating the structural resemblance (dimensions, handedness, polarity) between the two helical backbones. $\mathbf{b}$, Application to the construction of a composite Cys2His2 zinc finger with a $\beta \beta \alpha$ fold $\mathbf{c}$, Sequence of designed composite zinc finger ${ }^{\text {urea }}$ FN3 and the native zinc finger ${ }^{\text {native }}$ FN3 derived from Zif268. 
a

Microwave assisted SPS

Conventional SPPS

$\mathrm{O}^{-\mathrm{Cl}}$

2-Chlorotrityl resin

[a. $2 \times$ (Fmoc-AA-OH,

$\left.\begin{array}{l}\text { BOP, HOBT, DIEA, DMF) } \\ \text { b. piperidine, DMF }\end{array}\right]_{6}$

c. $2 \times$ (Boc-Pro-OH

BOP, HOBT, DIEA, DMF)

d. hexafluoro-2-propanol, DCM

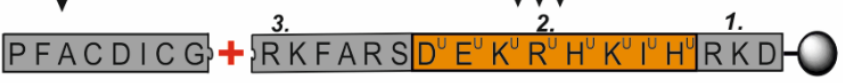

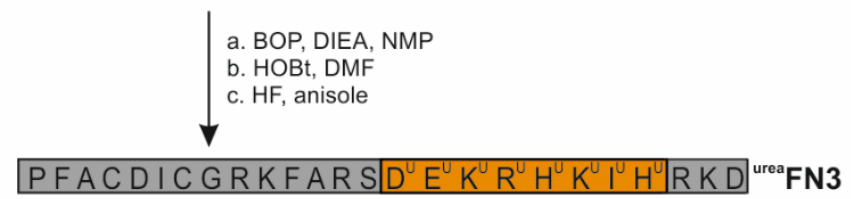

b

$[\mathrm{M}+4 \mathrm{H}]^{+}$

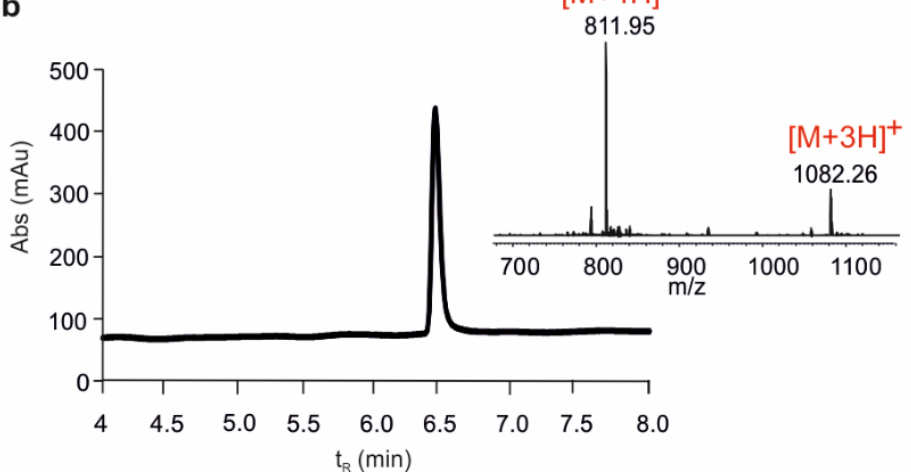

Figure 2. Synthesis of urea Fn3. a, General Scheme illustrating the fragment condensation approach on solid-support which was used to assemble the composite zinc finger. $\mathbf{b}$, HPLC trace and mass spectrometry data of the purified oligomer. Note: for clarity reasons all the side-chain protecting groups have been omitted. 

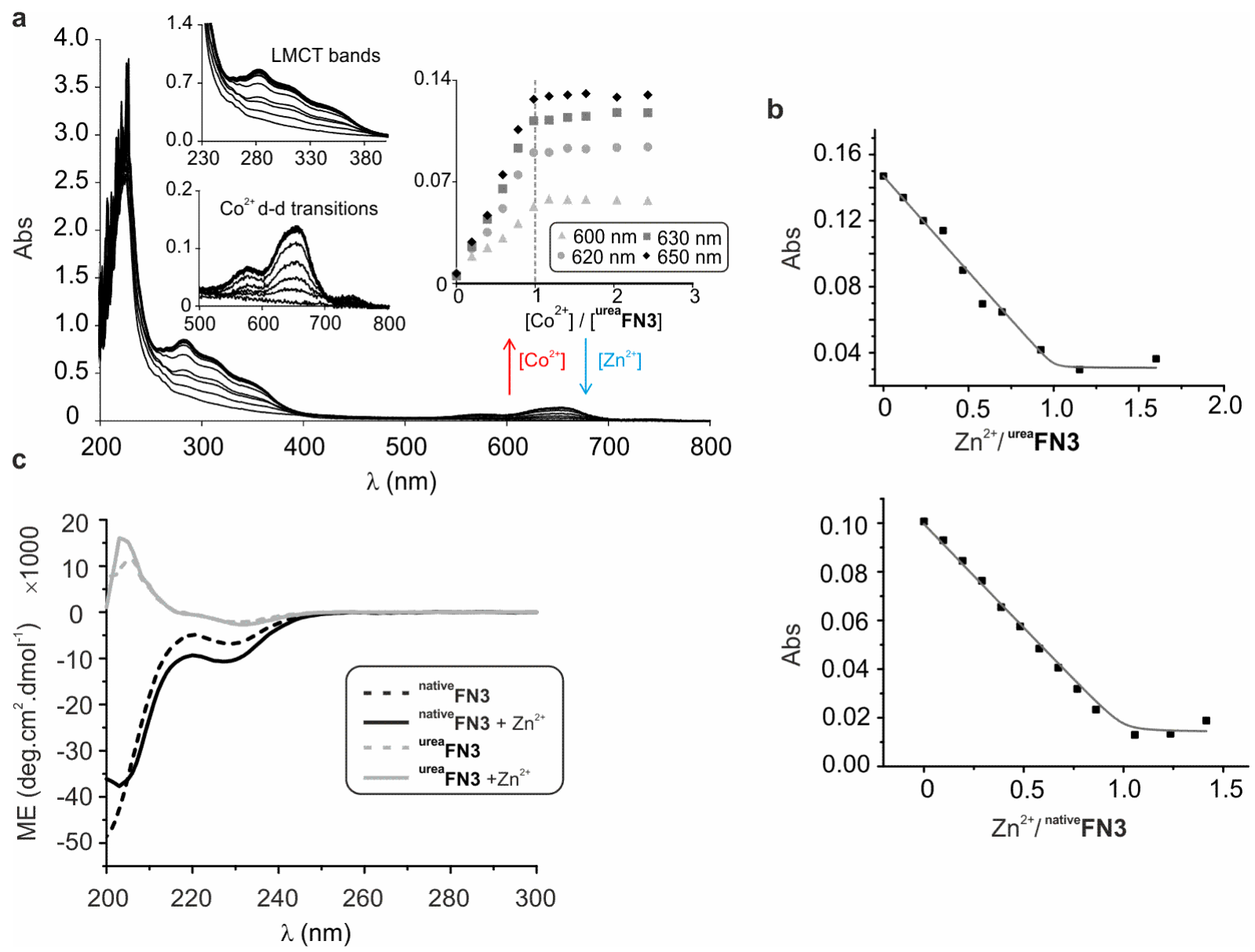

Figure 3. Spectroscopic analysis of $\mathrm{Zn}^{2+}$ binding to ${ }^{\text {urea }} \mathrm{Fn3}$. a, UV-Vis titration of ${ }^{\text {urea }} \mathrm{Fn}$ with excess $\mathrm{CoCl}_{2}$. The Inset on the left present a zoom on the regions corresponding to the LMCT bands and $d-d$ transitions indicative of a tetrahedral coordination of $\mathrm{Co}^{2+}$. The inset on the right shows the concentration dependent increase of the signal upon addition of $\mathrm{Co}^{2+} \mathbf{b}$, Progressive disappearance of this signature at $650 \mathrm{~nm}$ upon competitive titration with $\mathrm{Zn}^{2+}$ and curve fitting using a 1:1 binding model. c, CD signature of urea $F \mathbf{3}$ and native $F n 3$ in the absence and upon addition of one equivalent of $\mathrm{Zn}^{2+}$. 
a

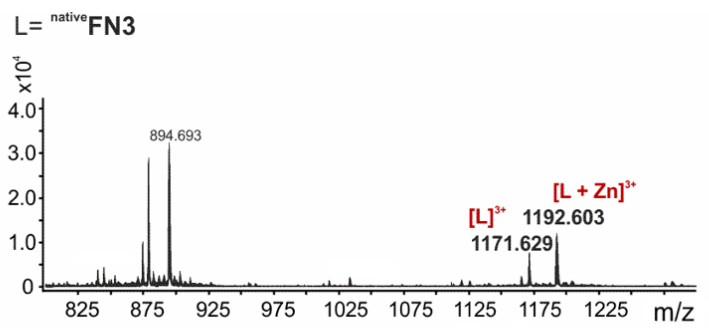

b

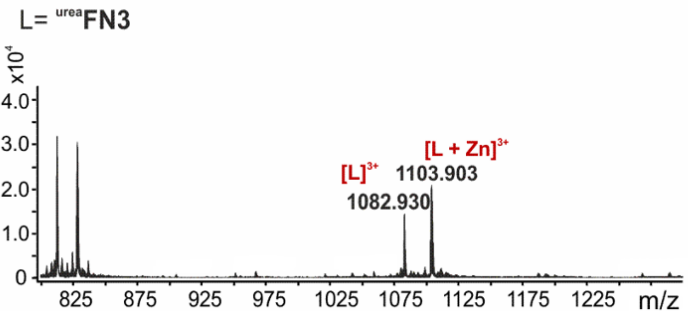

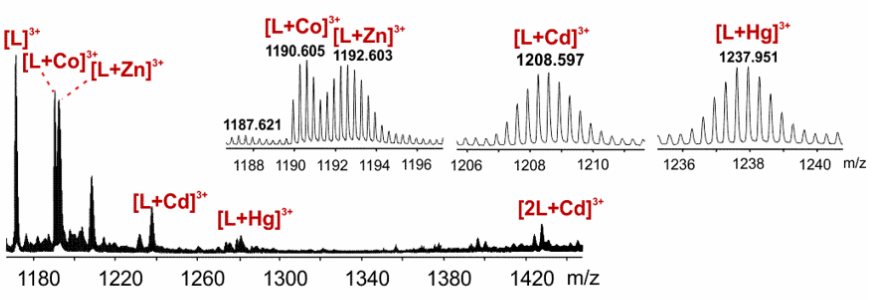

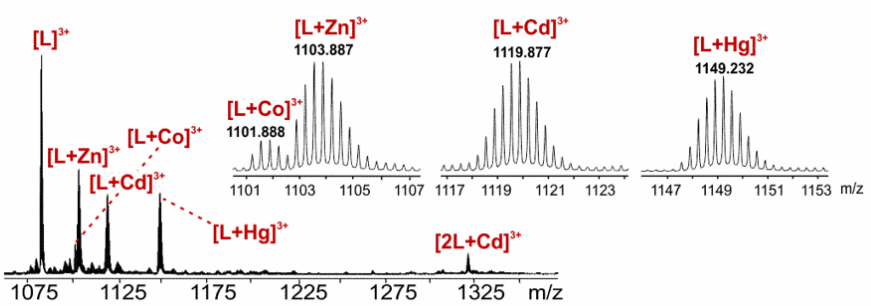

Figure 4. ESI-MS analysis. a, on the left: ESI-MS profile of the native peptide in the presence of 1 equivalent of $Z \mathrm{nAc}_{2}$, that shows the formation of predominantly a $1: 1$ complex between metal and peptide. On the right: ESI-MS profile of $75 \mu \mathrm{M}$ of native peptide in the presence of $15 \mu \mathrm{M} \mathrm{of} \mathrm{ZnAc}_{2}$, $\mathrm{CoCl}_{2}, \mathrm{CdAc}_{2}$ and $\mathrm{HgAc}_{2}$, respectively. The peptide shows similar affinities for $\mathrm{Co}^{2+}$ and $\mathrm{Zn}^{2+}$, with which it forms predominantly 1:1 complexes (as demonstrated by the zoom on the distribution of charge). The peptide shows lower affinity for $\mathrm{Cd}^{2+}$ and the presence of complexes with mixed stoichiometry with $\mathrm{Cd}^{2+}$ is observed. Extra care must be taken with the intensity ratio of zinc finger$\mathrm{Hg}^{2+}$ because the affinity og $\mathrm{Hg}^{2+}$ for $\mathrm{NH}_{3}$ (from the ammonium acetate) is significantly higher than the other metal. $\mathbf{b}$, on the left: ESI-MS profile of the chimeric Zinc Finger ${ }^{\text {urea }}{ }^{\mathrm{Fn} 3}$ in the presence of 1 equivalent of $\mathrm{ZnAc}_{2}$, that shows the formation of predominantly a $1: 1$ complex between metal and oligomer. On the right: ESI-MS profile of $75 \mu \mathrm{M}$ of chimeric Zinc Finger in the presence of $15 \mu \mathrm{M}$ of $\mathrm{ZnAc}_{2}, \mathrm{CoCl}_{2}, \mathrm{CdAc}_{2}$ and $\mathrm{HgAc}_{2}$, respectively. The oligomer shows similar affinities for $\mathrm{Cd}^{2+}$ and $\mathrm{Zn}^{2+}$, and forms 1:1 complexes with the latter, as demonstrated by the distribution of charge. The formation of both a 1:1 and 2:1 oligomer/metal complexes is observed with $\mathrm{Cd}^{2+}$. The chimeric Zinc Finger shows lower affinity for $\mathrm{Co}^{2+}$. 
a

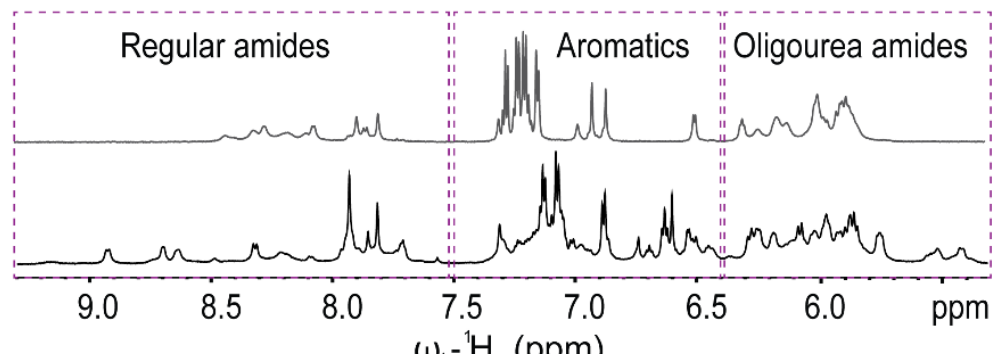

b
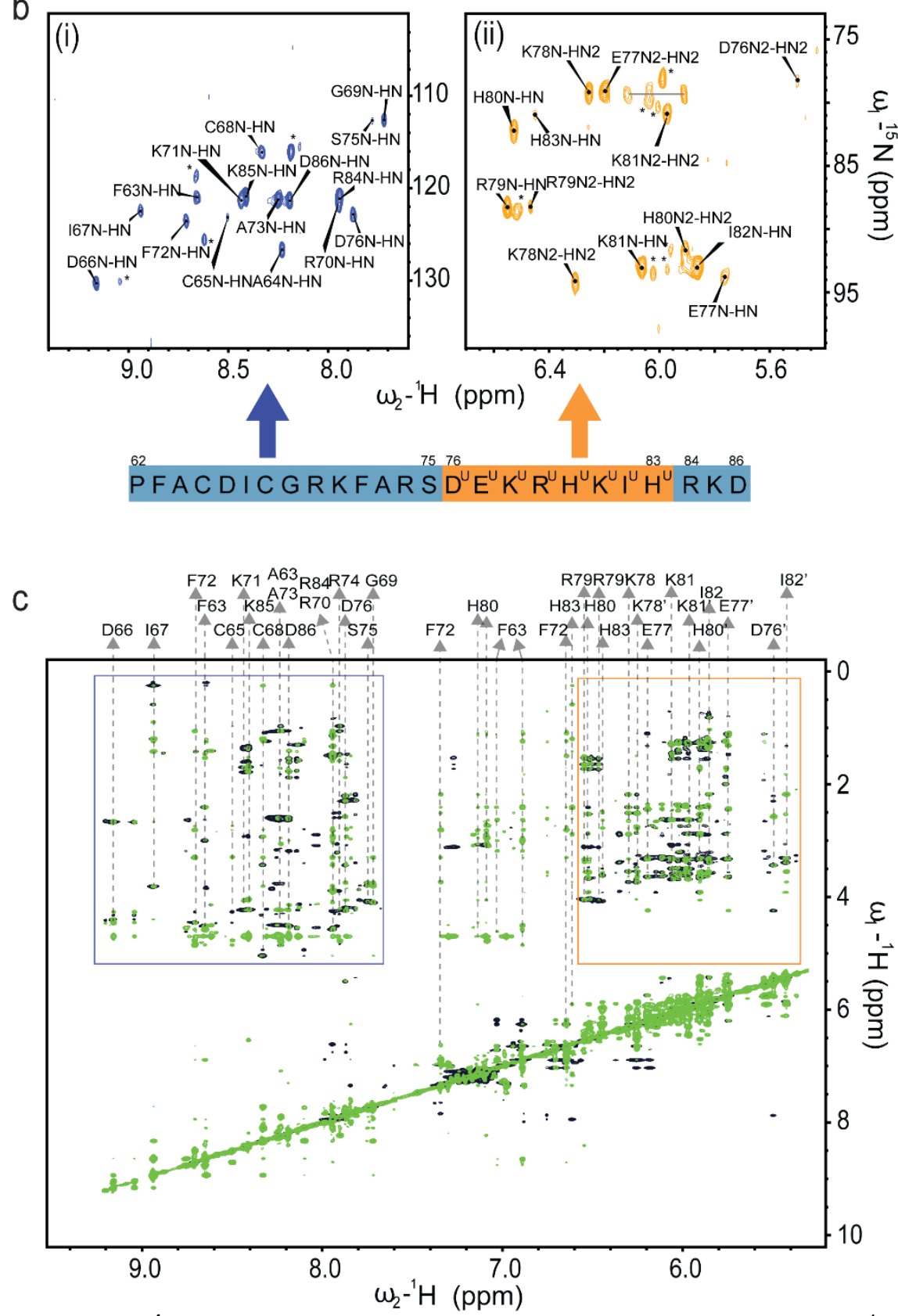

Figure 5. ${ }^{1} \mathrm{H}$ NMR analyses of urea FN3. a, Comparison of $1 \mathrm{D}{ }^{1} \mathrm{H}$ NMR spectra of ${ }^{\text {urea }} \mathrm{FN} 3$ in the absence (top) and in the presence of zinc cation (bottom). b, HN HSQC spectra of urea FN3 (left) $\mathrm{H}^{N}$ from the regular amide protons and (right) $\mathrm{H}^{N}$ and $\mathrm{H}^{N 2}$ from the oligourea amide protons. Oligourea residues (76-83) are colored in orange whereas regular $\alpha$-amino acid residues are shown in blue. c, 2D ${ }^{1} \mathrm{H}-{ }^{1} \mathrm{H}$ TOCSY (green) and NOESY (black) NMR spectra with a mixing time of 120 and 250 ms respectively. 

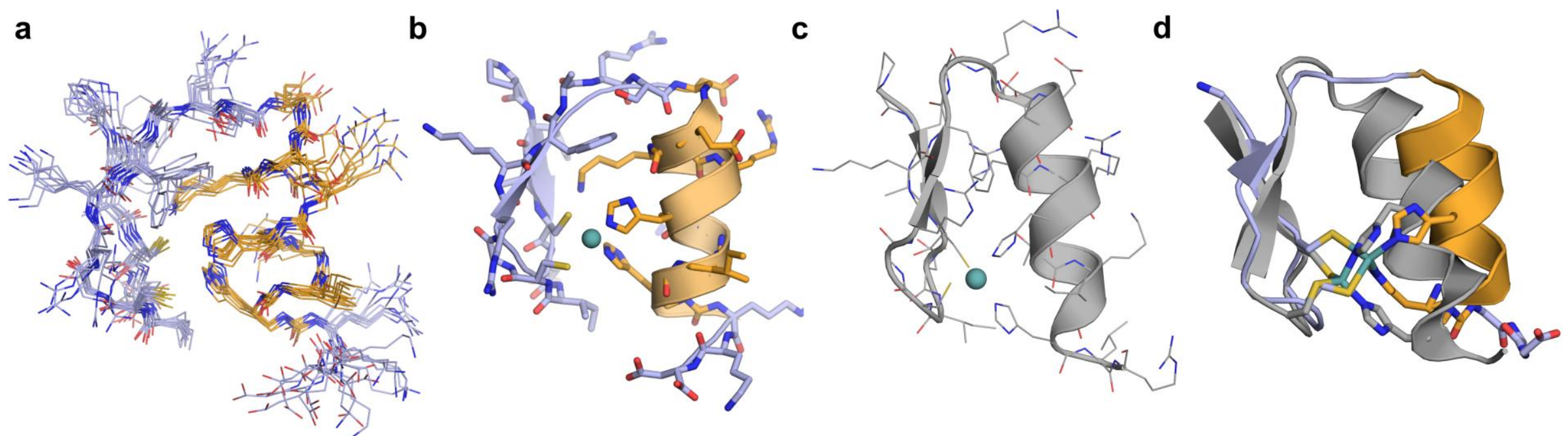

Figure 6. NMR-derived model of urea FN3. a, ten superimposed lowest-energy structures from the restrained molecular dynamics rMD-GB in explicit solvent with boundary conditions. The backbone CA RMDS between inter model is 0.6-0.7 $\AA$. Carbon atoms in the peptide segment are depicted in light blue whereas those in the oligourea segment are depicted in orange. $\mathbf{b}$, view of a representative conformation of urea $\mathrm{FN3}$ highlighting coordination to zinc metal ion. C, Comparison with the structure of ${ }^{\text {native }}$ FN3 as found in the X-ray crystal structure of Egr1 complexed with a duplex DNA sequence (PDB ID: $1 A A Y^{54}$ ). d, Structural alignment of the $\mathrm{N}$-terminal peptide segments (13 Ca) of urea FN3 (one representative low energy structure) and native FN3 (PDB ID: 1AAY). 
Figure 7. ' $\mathrm{H}$ NMR titration of Egr1 duplex DNA d(5'-AGCGTGGGCGT-3') and d(3'TCGCACCCGCA-5') by ${ }^{\text {urea}}$ FN3. a, Part of the $800 \mathrm{MHz} 1 \mathrm{D}^{1} \mathrm{H}$ NMR spectra of duplex DNA in the absence (i), and in presence of 0.5 equiv. (ii), 1 equiv. (iii), 1.5 equiv. (iv), 2 equiv. (v) and 2.5 (vi) of ${ }^{\text {urea }}$ FN3. The addition of increasing amount of ureaFN3 caused large chemical shift changes of mainly three imino protons of DNA duplex, G2, G4 and an ambiguous imino marked with an asterisk. $\mathbf{b}$, Zoomed region of the ${ }^{1} \mathrm{H}-{ }^{1} \mathrm{H}$ NOESY spectra showing chemical shift variation crosspeaks of $\mathrm{H} 8$ from $\mathrm{C}$ bases and imino protons of $\mathrm{G}$ bases upon addition of 2.5 molar equivalents of ${ }^{\text {urea }}$ FN3. 


\section{TOC graphic}

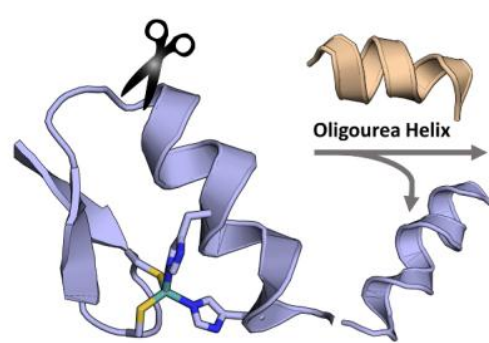

Native Zinc Finger Motif

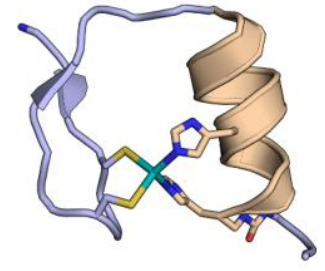

Artificial Zinc Finger 